\title{
A Comparative Analysis of War Metaphors in COVID-19 Reports in New York Times and China Daily
}

\author{
Yanmei Xiao* \\ Southwestern University of Finance and Economics, Chengdu 611130, Sichuan Province, China
}

\begin{abstract}
This paper analyzed the use of war metaphors in COVID-19 news reported by the New York Times (NYT) in comparison to the China Daily from the $1^{\text {st }}$ of February 2020 to the $29^{\text {th }}$ of February 2020 . Based on self-selected corpus from these two newspapers, a study was conducted to compare the contrasting lexis between NYT and China Daily, as well as to analyze the reasons for their differences using the Critical Metaphor Analysis (CMA). It was found that China Daily preferred using war metaphors in COVID-19 reports and war-related words such as "fight," "combat," and "battle." These words appeared frequently which demonstrated that Chinese people were fighting against the pandemic. However, these words were far less used in the NYT reports compared to China Daily and the use of these words were more related to the election, trade war, etc. This reflected their focus which was more on the impact of COVID-19 on politics and the economic sector.
\end{abstract}

Keywords: COVID-19; War metaphor; Critical metaphor analysis

Publication date: May, 2021; Publication online: 31 May, 2021

*Corresponding author: Yanmei Xiao, 1639466023@qq.com

\section{Introduction}

COVID-19 is causing enormous impacts on politics, economy, and the society. ${ }^{[1]}$ It has drawn interests from many fields. To understand the pandemic, news and reports from various channels are necessary. As metaphors have been deeply rooted in the minds of humans, a substantial amount is frequently used in news reports. In this study, the focus is on war metaphors since it is the most frequently used. In addition to that, people have grown accustomed to its use in the context of diseases such as, in cancer, SARS and H7N9. ${ }^{[2]}$

There were many research conducted in regard to the use of war metaphors in relation to COVID19. However, it is rare that they focus on the comparison of using war metaphors in a Chinese and an American newspaper based on the Critical Metaphor Analysis (CMA). This research is conducted for the purpose of understanding the differences of using contrasting lexis between the American and Chinese media, namely, NYT and
China Daily using CMA.

\section{Literature Review}

Charteris Black stated in his book that CMA is an approach to the analysis of metaphors which aims to reveal the profound intentions of language users. ${ }^{[3]}$ There are three levels in CMA, which are metaphor identification (linguistics), interpretation (pragmatic), and explanation (cognitive). In this analysis, metaphor identification was conducted with reference to previous studies on war metaphors, while metaphor interpretation was based on the understanding of the relations between the metaphor used and the writer. Lastly, metaphor explanation was the understanding of the role of metaphors used on a social level and its persuasive functions. ${ }^{[4]}$

Using CMA as a theoretical basis, many research in regard to the use of metaphors in disease discussions and other fields were conducted. Chiang and Duann analyzed political metaphors in 
reporting SARS in three newspapers from Taiwan and Mainland China. ${ }^{[5]}$ Brawely and Gualda focused on the ideology of war metaphors in the context of coronavirus used by leaders from different regions and countries. ${ }^{[6]}$ Leo and David made a critical metaphor analysis of Malaysian political discourse during COVID-19. ${ }^{[7]}$ Rohela and Sinha stated that by applying war metaphors in public discourse of COVID-19, it may cause more harms than benefits. ${ }^{[8][9]}$ Ding and Yang analyzed the expressions and constructions of war metaphor in COVID-19 reports. ${ }^{[10]}$ Luo made a comparative analysis of metaphors on China's and Britain's news reports regarding China's cross-border ecommerce. $^{[4]}$

There was minimal research in regard to comparative analysis of war metaphors in COVID19 reports. Therefore, this paper analyzed the differences in using war metaphors in NYT and China Daily news reports.

\section{Methodology}

\subsection{Data collection}

The study was conducted based on a self-selected corpus. Language materials were collected from NYT and China Daily from the $1^{\text {st }}$ of February 2020 to $29^{\text {th }}$ of February 2020. Reports with "COVID19 ," "coronavirus," "the epidemic," or "virus" in their title were selected. There were 155 reports in total from February $1^{\text {st }}$ to February $29^{\text {th }}$ in China Daily and out of that amount, 102 reports were selected with a total of 61,105 words. However, only 50 reports were selected from NYT with a total of 66,401 words in order to control the total number of words in this study.

\subsection{Research procedure}

With reference to previous studies on the analysis of war metaphors, war-related words were categorized according to various aspects of war. ${ }^{[3][11][12]}$ As these metaphorical words were comprehensively analyzed and accepted by these scholars, this categorization which is listed in Table 1 may have high reliability. The corpus tool used in this research was Antconc (version 3.5.8).

Each of these words was searched in the selfselected corpus. The 10 most frequent words in NYT and China Daily respectively, were selected for a detailed analysis of their differences and the reasons for these differences based on CMA by citing examples from the corpus.

Table 1. Categorization of war-related words

\begin{tabular}{lc}
\hline Aspects of war & War-related words \\
\hline Description of a war & war, campaign, aggression, battle, invasion \\
Consequences of a war & victory, defeat, conquer, beat, surrender, death \\
Participants of a war & hero, enemy, soldier, rival, veteran, victim, warrior \\
Process of a war & fight, struggle, attack, combat, defend \\
\hline
\end{tabular}

\section{Results and Discussion}

The words listed above were searched in the selfselected corpus, of which the hits are shown in Table 2. For example, "war*" meant that all words begin with "war" were searched in the corpus and hits were counted manually.

From Table 2, "battle*" and "war*" were the two most frequent words used in China Daily while "war*" and "campaign*" were the most frequently used ones in NYT. This is an evidence that media reports tend to regard COVID-19 as a form of war. However, in the search for related words in the corpus, "battle" and "war" in China Daily were only used in direct relation to coronavirus as the example shown below. While in NYT, it was not the case (Example 1 and 2). 
Table 2. Frequency of related in China daily and NTY

\begin{tabular}{|c|c|c|c|}
\hline Aspects of wars & Related words & China Daily (hits) & New York Times (hits.) \\
\hline \multirow{5}{*}{ Description of a war } & war* & 22 & 19 \\
\hline & campaign* & 7 & 7 \\
\hline & aggression* & 0 & 0 \\
\hline & battle* & 50 & 4 \\
\hline & invasion* & 0 & 0 \\
\hline \multirow{6}{*}{ Consequences of a war } & victory* & 12 & 2 \\
\hline & defeat* & 3 & 0 \\
\hline & conquer* & 1 & 0 \\
\hline & beat* & 2 & 1 \\
\hline & surrender* & 0 & 0 \\
\hline & death* & 59 & 54 \\
\hline \multirow{7}{*}{ Participants of a war } & hero* & 5 & 3 \\
\hline & enemy* & 6 & 1 \\
\hline & soldier* & 2 & 0 \\
\hline & rival* & 1 & 5 \\
\hline & veteran* & 3 & 0 \\
\hline & victim* & 2 & 5 \\
\hline & warrior* & 1 & 0 \\
\hline \multirow{5}{*}{ Process of a war } & fight* & 146 & 36 \\
\hline & struggle* & 5 & 11 \\
\hline & combat* & 24 & 2 \\
\hline & attack* & 20 & 6 \\
\hline & defend* & 1 & 12 \\
\hline
\end{tabular}

Example 1: the central government...to reinforce Wuhan in the war against the epidemic. (China Daily) Example 2: New orders for products...slumped 9 percent in 2019 because of President Trump's trade war... (NYT)

As shown in Example 2, NYT mentioned other interests of the U.S. government. Eleven out of the nineteen hits of "war*" in NYT was about the U.S.China trade war. Only four were related to the pandemic. This may be due to the opinions of the U.S. government towards China, whereby in this pandemic, the U.S. government fears that China would fail to fulfill the agreement signed at the White House.
In the "End of a war" category, "death*" was the most frequent word found in both, the China Daily and NYT. This suggested that they were concerned about the deaths or death rates caused by COVID-19. Death or death rates are important measures to value efforts in stopping the spread of the virus. It can also evoke fear among the audience, hence, taking measures to end the pandemic.

Example 3: China's death toll reached 2,663 on Tuesday. (China Daily)

Example 4: France Confirms First Death in Europe From Coronavirus. (NYT) 
In the "Participants of a war" category, China Daily mentioned "hero*" and "enemy*" the most which suggested the counter position between human beings and the virus. The word "hero," was used in the context of the determination of the "heroes" in China to win the battle against COVID-19. On the other hand, NYT focused more on "victim*" and "rival*" in which 4 out the 5 hits of "rival" were concerned with President Trump's political rivals. This may have suggested that the president was worried about the challenges brought by COVID19 in his re-election.

Example 5: Considering the urgency and considering that we are fighting with a very dangerous enemy...(China Daily)

Example 6: In an interview with Sean Hannity of Fox News, President Trump insulted his potential 2020 rivals...(NYT)

In the "Process of a war" category, "fight*" is the most frequent word used in China Daily as well as the NYT. It was not surprising that the word, "fight" appeared frequently. In China Daily the use of "fight" and "combat" were all related to COVID19 except one, that was regarding SARS. However, reports in NYT were significantly different from that in China Daily. Instead of directly relating to COVID-19, the related words were used in relation to the United States governance in most cases as shown in example 8.

Example 7: Fight against coronavirus is a call to arms for all. (China Daily)

Example 8: He defended the White House's handling of the response to the coronavirus... (NYT)

Table 3 shows the differences in the use of related words in both newspapers. Reports in China Daily used more metaphors than NYT which is shown by the frequency of these words. Secondly, in China
Daily, reports tend to focus more on the "Process of war" category while NYT has more emphasis on the "Consequence of a war" category.

Table 3. Ten most frequent words in the China Daily and New York Times

\begin{tabular}{|c|c|c|c|}
\hline \multicolumn{2}{|c|}{ China Daily } & \multicolumn{2}{|c|}{ New York Times } \\
\hline Frequent words & Hits & Frequent words & Hits \\
\hline fight* & 146 & death* & 54 \\
\hline death* & 59 & fight* & 36 \\
\hline battle* & 50 & war* & 19 \\
\hline combat* & 24 & defend* & 12 \\
\hline war* & 22 & struggle* & 11 \\
\hline attack* & 20 & campaign* & 7 \\
\hline victory* & 12 & attack* & 6 \\
\hline campaign* & 7 & victim*/ rival* & 5 \\
\hline enemy* & 6 & battle* & 4 \\
\hline struggle*/ hero* & 5 & hero*/ survive* & 3 \\
\hline
\end{tabular}


In reports of China Daily, war-related words, like "fight" and "battle," offers an ideation that Chinese people have the determination and bravery in addition to making every effort to counter the pandemic. On the other hand, by reporting death or death rates, it evokes a sense of fear. Hence, the use of war-related words, may instill fear into the audiences, but depending on the words used, it may also stir up positive reactions and people's determination.

In NYT, war-related words were more related to President Trump's administration, such as the election, trade agreement etc. However, this study was conducted only in the month of February and in that short period of time, the U.S. government may not have taken the pandemic seriously.

From this study, questions are raised in regard to the reasons on why news reports have preference in applying war metaphors in reporting COVID-19 and the differences in the choice of these words between the China Daily and NYT. In China, besides the tradition of perceiving "disease is war," President Xi described the pandemic as "people's war" in order to engage all citizens to counter COVID-19. In addition to that, President Trump also described himself as a "wartime president" in this pandemic. Political leaders view the coronavirus as people's common enemy. Furthermore, the use of war metaphors in news reports will have more appeal, hence, emphasizing the importance of a specific news for better dissemination. ${ }^{[12]}$ To answer the second question, besides having different subject of focus, the choice of metaphorical words may depend on the political and historical experiences of their social background. ${ }^{[6]}$

\section{Conclusion}

In NYT and China Daily, the focus on death caused by COVID-19 would have instilled fear in their audiences. While China Daily emphasized on situations within the territory of China, NYT monitored the issue around the world such as in Europe and China. China Daily preferred using war metaphors in COVID-19 reports and words such as "fight," "combat," and "battle," appeared frequently which demonstrated the determination of the government and citizens in fighting against this pandemic. While in NYT, war-related words were far less used than that in China Daily and most of them were not directly related to the pandemic. Instead, they were related to elections, trade wars, etc. Hence, this reflected their focus which was more on the impact of COVID-19 on politics and the economic sector.

\section{Disclosure statement}

No conflicts of interest.

\section{References}

[1] Sabucedo, J., Alzate, M., Hur, D(2020). COVID-19 and the Metaphor of War. International Journal of Social Psychology (Online version).

[2]Zhang, W., Mao, H., Wang, S(2015). An Analysis of Metaphors and Frames in Official Media Reports of Public Health Emergencies. Journal of Fujian Normal University (Philosophy and Social Sciences Edition), 2(9): 100-108.

[3] Charteris-Black, J(2004). Corpus approaches to Critical Metaphor Analysis. Palgrave Macmillan, 113-120.

[4]Luo, X., Dong, J. \& Zhang, X. (2019). A Comparative Study of Metaphors in China's and Britain's English News Reports on Chinese Crossborder E-commerce. International Journal of Liberal Arts and Social Science, 7(7), pp. 44-52.

[5]Chiang, W., Duann, R(2007). Conceptual metaphors for SARS: 'war' between whom?. Discourse \& Society, 18(5): 579-602.

[6]Brawley, E., Gualda, E(2020). Transnational Social Implications of the Use of the "War metaphor" Concerning Coronavirus: A Bird's Eye View. Culture e Studi del Sociale, Special issue, 5(1): 259-272.

[7]Leo, A., David, M(2020). A Critical Metaphor Analysis on Malaysia's Gazetted Metaphors amid the Movement Control Order: A COVID-19 Episode. Journal of Humanities and Social Science Research, 2(10): 193-204.

[8]Rohela, P., Bhan, A., Ravindranath, D., Bose, 
D., Pathare, S(2020). Must there be a "war" against coronavirus? Indian Journal of Medical Ethics.

[9] Sinha, P(2020). Stop Fighting the Coronavirus. Journal of Wellness, 2(1).

[10]Ding, J., Yang, H(2020). The Virus as the Other: Discourse Analysis on Metaphor of COVID-19. Journal of Guangzhou University (Philosophy and Social Sciences Edition), 4: 104112.

[11]Chen, K(2012). Comparative Analysis of War Metaphor between Business English Discourse and Political Discourse and Economic Discourse - A Corpus-Based Research. Journal of Changchun University of Science and Technology, 7(3): 86-89.
[12]Liu, Z(2019). Trauma, War, Beginning and Rebirth: Metaphors in the Memorial Reports of the "10th Anniversary of Wenchuan Earthquake". Journalism \& Communication Review, 72(6): 6879.

[13]Wen, J(2010). Advantages and Disadvantages of War Metaphors in the Reports of Public Health Emergency in China. Journal of Hubei TV University, 30(10): 105-106.

[14]Nartey, M(2019). 'I shall prosecute a ruthless war on these monsters...': a critical metaphor analysis of discourse of resistance in the rhetoric of Kwame Nkrumah. Critical Discourse Studies, 16(2): 113-130. 